\title{
The Family Way: How Entrepreneurial Values Help Businesses Thrive Over Generations
}

\author{
Ritch Sorenson (University of St. Thomas)
}

\section{KEYWORDS: Family Business.}

Family firms enjoy a competitive advantage when they organize around a set of strong values. A study of large family businesses such as Cargill, IKEA, Tyson Foods, and Bechtel (Miller and Le Breton-Miller, 2011) summarized the values that contributed to their success. Some of those values are distinctively entrepreneurial: continuity in pursuing their dream and the capacity to adapt and renew their firm.

The family firm can't survive unless it sustains those entrepreneurial values across the business life-cycle and from one generation to the next. The failure to do so may explain why so many family businesses fail. Studies have shown that only a third of family firms make it to the second generation, and only 12 percent to the third (e.g., Beckhard \& Dyer, 1983). Family businesses that do survive through multiple generations often need to grow to support an increasing number of family owners. However, as family businesses mature, they may enter a period of decline unless they find ways to innovate, infuse some entrepreneurial thinking into the enterprise, and revitalize themselves. These are challenges that the family firm's values and culture will either help or hinder.

\section{The Role of Entrepreneurial Values}

Values play a special role in family firms. Interaction between the family and the business often reflect and express family values, forming distinct family firm cultures (Sorenson, 2014). Often these values are informally expressed as, "The way we do things," and are used to guide the decisions and strategic planning for the business.

While initial business values are largely based on founder values (Schein, 1983), subsequent generations of owners align around a new reality: "We are in this for the long-term." Guided by the owning family, the firm may transition from a culture that promotes rapid growth to one that promotes stable, long-term growth (Miller \& Le Breton Miller, 2011). Since the owning family is interested in long-term business viability, they need to continually review and, if necessary, revitalize values that promote entrepreneurship.

What are the values that enable a family business to be entrepreneurial? A study of small-to-medium sized businesses by Zahra, Hayton, and Salvato (2004) identified several of them, and contrasted them with nonfamily firms. They sought to identify family firm values associated with entrepreneurship, which they defined as being proactive, innovative and willing to take calculated risks. Here is a summary and commentary on that study-- specifically, their findings on how entrepreneurship in family firms is related to the values of:

- long-term orientation,

- strong family-firm culture,

- external orientation,

- decentralized decision-making, and

- both individual and collective orientations.

I conclude with comments about governance practices family firms can develop that help to sustain a business culture that supports entrepreneurial values.

\section{Long-term Orientation}

The defining characteristic of a family firm is a long-term orientation. For example, a recent study by $\mathrm{Yu}$, Brigham, Sorenson and Lumpkin (2012) summarized the data from 12 years of family business research and found that family firms are characterized by a long-term orientation, as revealed in a governance focus on strategic and succession planning. A firm becomes a family firm when the owners decide to keep business ownership in the family for the long term, as opposed to shutting the doors or selling the business to investors. Thus, to sustain long-term viability, they keep an eye on short-term financials but also focus on goals that produce the best long-term outcomes.
Copyright ( $)$ The Authors. Entrepreneur \& Innovation Exchange is published at EIX.org. This is an open access article under the terms of the Creative Commons Attribution-NoDerivs License, which permits use and distribution in any medium, provided the original work is properly cited and no modifications or adaptations are made. View EIX.org Authorship Terms at https://eix.org/terms 
Zahra et al. (2004) described a strategic focus in family firms as one that yields value creation that will sustain the owning family over the long-term. In short, family business owners are guided less by financial controls that emphasize short-term financial targets and quotas, and more by strategic controls tied to firm goals. In an earlier study, (1996) Zahra found that when Fortune 500 firms emphasized financial controls, they had a shortterm orientation that limited entrepreneurial activity. Conversely, businesses with a long-term orientation, associated with strategic controls, promoted entrepreneurial activity. Those results resulted in the expectation that a long-term strategic orientation in a family firm is related to entrepreneurial activity (see also Lumpkin, Brigham \& Moss, 2010).

In their 2004 study, Zahra and his colleagues obtained data from 536 small to medium-sized firms -218 family firms and 318 non-family firms. Managers in these firms completed questionnaires about firm and entrepreneurial values. Their study used two indicators to demonstrate short- and long-term orientation:

1) Emphasis on financial controls indicated a shortterm orientation; and

2) Emphasis on strategic controls and related firm goals represented a long-term orientation.

These findings showed a significant difference between family and non-family firms. Financial controls, which were more highly used in non-family firms, were negatively related to entrepreneurship. Strategic controls, which were more highly used in family firms, were positively related to entrepreneurship. The authors reasoned that firms interested in short-term financial paybacks are less willing to be entrepreneurial than firms focused on long-term activities that created value.

Thus, the defining characteristic of family firms - a longterm orientation-can make the firm more entrepreneurial. The desire to keep the business in the family over the long term can result in a long-term competitive advantage.

\section{Strong Culture}

A characteristic of a strong culture is having a clearly defined set of values (Sorenson, 2014). Family firms with strong cultures tend to emphasize core values in the family and their businesses. Often, the founder infuses values into the firm's culture that promote initial growth. Succeeding generations of owners tend to reinforce founding values, and add other values that support long-term sustainability. When the owning family embraces the founder's values (Sorenson, Goodpaster \& Hedberg, 2009), those values continue to be reflected in the firm.

Because family business owners have a common family history, firms privately owned by family members are more likely to have a shared and defined set of values than firms owned by unrelated investors. And, one would expect an owning family to use that defined set of values -- for better or worse -- to guide the firm. Adding influential non-family owners may constrain the extent to which the owning family can promote its family values in the firm. For example, family owners may prefer longterm growth, but non-family investors may desire shortterm financial returns.

In their study, Zahra and his colleagues (2004) found a significantly stronger relationship between cultural values and entrepreneurship in family than in non-family firms. This relationship is explained in depth in Miller and Le Breton-Miller's (2005) Managing for the Long Run: Lessons in Competitive Advantage from Great Family Businesses. In this book, Miller and Le BretonMiller illustrate how vilified attributes of family firms, such as stable strategies and clan cultures, can actually provide a competitive advantage.

\section{External Orientation}

Zahra and his colleagues (2004) found entrepreneurship is significantly related to an external orientation in both family and non-family firms. Instead of valuing only internal development, firms that value practices such as monitoring the external environment enable business leaders to identify and respond to emerging entrepreneurial opportunities. Zahra and his colleagues (2004) indicate that firms with an external orientation

- are attuned to the innovations and practices of rivals

- focus on identifying problems and finding solutions, and

- are in in touch with market trends indicative of emerging opportunities.

While founders of family firms are likely to have an external orientation, succeeding generations of owners 
may need to be taught to appreciate and promote an external orientation in their firms.

\section{Decentralization}

Centralization places the decision-making in the hands of a few select individuals, often family members in family firms. A study of family business cultures by Dyer (1986) found that a high percentage of firms he studied were paternalistic. Family firms with a paternalistic culture tend to centralize decision-making, placing control in the hands of the owning family.

Decentralized family firms trust non-family employees and are willing to share decision-making, so decisions can be made close to the source of problems. This helps the family firm respond proactively to entrepreneurial opportunities. Decentralized decisionmaking is stronger in cultures that sustain open communication and allow employees to challenge current practices (Sorenson, 1999).

Zahra et al. (2004) found that entrepreneurial family firms encouraged decentralized rather than centralized decision making. They note that such firms are open to change, have controls that allow for individual initiative, and maintain open communication systems.

\section{Individual and Group Orientation}

Cultures across the world vary in the extent to which they have an individualistic or group orientation. For example, the United States is more individualistic, and Japan is more group oriented (e.g., Hofstede, Hoftstede \& Minkov, 2010). Firms in the United States tend to be innovative and develop new ideas, while firms in Japan tend to be good at implementing ideas. When looking at this aspect of family firm culture, Zahra et al. (2004) found that entrepreneurial family firms encourage both individualism and a group orientation.

Because individualism tends to stimulate idea creation, and a group orientation enables employees to share knowledge and cooperate in implementing new ideas, organizations that emphasize only one approach will have relatively less entrepreneurial success. Firms that place a high value on individualism may have difficulty rallying cooperative support to implement new ideas, whereas organizations that place a high value on collectivism are not likely to produce radical innovations. Thus, organizations like family firms that place an emphasis on both individual and group can enhance entrepreneurship by the developing a culture that both creates new ideas and successfully implements them.

Miller and LeBreton Miller (2011) describe innovative and collaborative cultures in family firms this way:

"If individual latitude and initiative are important in generating ideas and getting the best work out of people, collaboration within and across business units is necessary to develop those ideas into usable products and technologies."

They use as examples such as Corning and Motorola to illustrate how firms expect their employees to have both technical expertise and social ability. Corning, for example, expects to have people who are independent thinkers but also team players. Thus, a clan-like culture that encourages informal communication, rather than rigid channels, may enable family firms to be both individualistic and team oriented.

\section{Commentary}

This commentary focuses on how family firm governance can promote entrepreneurial values. The primary elements of family firm governance are a familyowner council, a board of directors and top management. Here are some ways owners can use their family-owner council to promote and communicate values, including entrepreneurial values, to the board and top-level management. 
The kinds of entrepreneurial values owners can recognize and promote within family owner councils include those revealed by Zahra et al. (2004). Promotion of values is important because values can provide family businesses an entrepreneurial competitive advantage. As was indicated above, Zahra and his colleagues found that family firms not only have strong cultures, but also a set of cultural values that are related to entrepreneurship. Specifically, compared to non-family firms, entrepreneurial activity in family firms is highly correlated with these values (Figure 1):

- both an individual and a collective orientation,

- decentralized decision-making, and

- a strategic-goal rather than financial-control orientation (see also Miller and Le Breton-Miller, 2004).

In addition, entrepreneurship in both family and nonfamily firms is correlated with valuing an external orientation.

The values identified by Zahra and his colleagues (2004) may not fit every family business culture. However, undoubtedly owners can find and promote a set of values related to innovation and entrepreneurship that make sense for their business.

Over time, organizations go through life cycles, such as birth, growth, maturity and decline (Kimberly \& Miles, 1980). And similarly, families pass through life cycles as ownership is passed from one generation to the next (Gersick et al., 1997). Maintaining a competitive entrepreneurial advantage across life cycles can be accomplished by clarifying owning family values, sustaining those values across generations of owners, and communicating those values clearly to the board and business leaders.

For the owning family to sustain entrepreneurial values in the second generation and beyond, they need an ownership governance structure that focuses attention on owner values. Successful owner governance structures includes both informal social events and formal family councils (Mustakallio, Autio, \& Zahra, 2002). Formality in decision-making increases agreement among owners (Sorenson, 1999).

Thus, entrepreneurship is likely sustained when, beginning in the second generation, owners formally agree on the entrepreneurial values that will guide the business. The founder may or may not have a role in this decision or in setting up a governance structure to sustain those values. However, a good governance system can consistently promote firm values across generations. Lack of formal owner governance may result in lack of clarity about values and the strategic goals for the business (see Mustakallio, et al., 2002; Sorenson, 1999).

When owners agree on values and expectations for the business, they can be used to guide activities such as selecting board members, overseeing board activities and clarifying expectations to the board, which can help align business strategy with owning family values. In later generations, which may have large numbers of owners, the fate of values is influenced by owners who serve on the ownership council or the board. Values will be retained when family representatives on the council and the board champion them.

Sustaining core values across generations will depend on the extent to which upcoming family business owners support core family values. Each generation needs repeated exposure to the importance of the values on which the business was founded. In the second generation and beyond, values can be sustained in regular family owner gatherings. For example, at annual shareholder meetings, owners can recognize and celebrate core family values. In addition, family members can be educated about how family values provide general guidance for business decision-making. Over time, next generation family members can be exposed repetitively to entrepreneurial values in action in the firm. When owners are not vigilant about maintaining core values across generations, they can become diluted or forgotten. Core values may be weakened when governance control is placed in the hands of individuals who do not appreciate the family culture (e.g., a trust).

In general, board members can look to family owners for business-related values. Board members would welcome clarity about family values and use them to guide governance decisions, especially in developing business strategy. Family members on the board can remind other members about owner expectations. For example, in Cargill, one of the largest family businesses in the world, eight of 12 the board members are part of the owning families.

In summary, when the owning family has a strong 
culture defined by common values, it can repeatedly make those values clear to the board of directors. Then, the board can use core family values as a guide in governing the business. Two main ways the owning family owners can convey values to the board are by having a clear family values statement and family representation on the board.

Each time board membership changes, attention can be given to aligning board members with family values. When the values are explicit, board members may find meaningful applications for the business. Values can inform the nature of family involvement with the board and the business.

\section{Conclusion}

In summary, values promote not only unity and cohesion, but also agility and innovation. Entrepreneurial values and other core family values play a distinct role in defining attributes of a strong culture in an entrepreneurial family business. As summarized in this paper, family firms that cultivate a strong family firm culture can integrate and retain entrepreneurial values in their family firms. Included among entrepreneurial values are those described in this paper: a long-term ownership perspective, decentralized decision-making, a focus on the external environment, and emphasis on both an individual and group orientation. Such valuedriven practices can enable family firms to balance the tension between innovation and sustainability. In today's rapidly changing environment, these attributes are critical to survival. In summary, the combination of entrepreneurial values and family values may enable family firms to cultivate the resilience that helps their enterprise thrive into the "third generation" and beyond.

\section{References}

Beckhard, R., \& Dyer, Jr., W. G. Managing continuity in the family business. Organizational Dynamics, 1983, Summer 5-12.

Dyer, Jr.,W.G. (1986) Cultural Change in Family Firms: Anticipating and Managing Business and Family Transitions. San Francisco, California: Jossey-Bass.

Dyer, W.G., Jr. (2003). The family: The missing variable in organizational research. Entrepreneurship Theory and Practice, 27(4), 401-416.

Gersick, K.E., Davis, J.A., McCollom-Hamption, M., \& Lansberg, I. (1997). Generation to Generation: Life
Cycles of the Family Business. Boston, Massachusetts: Harvard Business School Press.

Hofstede, G., Hofstede, G. J \& Minkov, M. (2010). Cultures and Organizations: Software of the Mind, 3rd ed. New York: McGraw-Hill.

Kimberly, J. and Miles, R. (1980). The Organizational life cycle. San Francisco: Jossey-Bass Publishers.

Lumpkin, G. T., Brigham, H. B., \& Moss, T. W., (2010). Long-term orientation: Implications for the entrepreneurial orientation and performance of family businesses. Entrepreneurship and Regional Development, 22, 3-4, 241-264.

Miller, D. \& Le Breton-Miller (2005). Managing for the Long Run: Lesson in Competitive Advantage from Great Family Businesses. Boston, Mass.: Harvard Business School.

Miller, D. \& Le Breton-Miller (2011). Governance, social identity, and entrepreneurial orientation in closely held public companies. Entrepreneurship Theory and Practice, 35 (5)1051-1076.

Mustakallio, M., Autio, E., \& Zahra, S. A. (2002). Relational and contractual governance in family firms: Effects on strategic decision making. Family Business Review, 15, 205-222.

Tàpies, J. \& Ward, J.L. (Eds.) (2008) Family Values and Value Creation: The Fostering of Enduring Values Within Family-owned Businesses. New York, NY: Palgrave, Macmillan.

Schein, E.H. (1983) The role of the founder in creating organizational culture. Organizational Dynamics, Summer.

Sharma, P., \& Nordqvist, M. (2008). A classification scheme for family firms: From family values to effective governance to firm performance. In J. Tàpies, \& J.L. Ward (Eds.), Family values and value creation: The fostering of enduring values within family-owned businesses (pp. 71-101). New York: Palgrave Macmillan Publishers.

Sharma, P. \& Salvato, C., (2011) Commentary: Exploiting and Exploring New Opportunities Over Life Cycle States of Family Firms. Entrepreneurship: Theory and Practice. November, pp 1199-1204 
Shanker, M.C., \& Astrachan, J.H. (1996). Myths and realities: Family businesses' contribution to the U.S. economy - A framework for assessing family business statistics. Family Business Review, 9(2), 107-123.

Sorenson, R. L. (1999). Conflict strategies used by successful family businesses. Family Business Review, 12, 325-339.

Sorenson, R.L. (2000). The contribution of leadership styles and practices to family and business success. Family Business Review, 13(3), 183-200.

Sorenson, R. L. (2014) Values in Family Business. In Leif Melin, Mattias Nordquist, and Promadita Sharma (Eds.) The Sage Handbook of Family Business.

Sorenson, R. L., Goodpaster, K. E., Hedberg, P. R., \& $\mathrm{Yu}, \mathrm{A} .2009$. The family point of view, family social capital, and firm performance: An exploratory test. Family Business Review, 22, 3, 239-253.

Ward, J. \& Dolan, C. (1998) Defining and Describing Family Business Ownership Configurations. Family Business Review, 11(4) pp 305-310.

Zahra, S.A., Hayton, J.C., Salvato, C. (2004) Entreprenuership in Family vs. No-Family Firms: A Resource Based Analysis of the Effect of Organizational Culture.

Zahra, S. A., Labaki, R., Abdel-Gwad, S.G. \& Sciascia, S. (2014) Family Firm and Social Innovation: Cultivating Organizational Embeddedness. In Leif Melin, Mattias Nordquist, and Promadita Sharma (Eds.) The Sage Handbook of Family Business. 